\title{
KEPEMIMPINAN KEPALA SEKOLAH DALAM PENGEMBANGAN PROFESIONALISME GURU
}

\author{
Rika Ariyani \\ Dosen Manajemen Pendidikan Islam STAI MSQ Bangko \\ E-mail: Rikaariyani46@yahoo.com
}

\begin{abstract}
Abstrak
Guru adalah jabatan profesi, oleh karena itu guru harus profesional. Sejumlah penelitian membuktikan bahwa guru yang profesional merupakan salah satu indikator penting dari sekolah berkualitas. Dengan demikian, pengembangan profesi guru perlu dilakukan. Pengembangan profesi guru merupakan suatu proses untuk membantu guru dalam melakukan pekerjaan secara efektif. Dan kepala sekolah sebagai pimpinan pendidikan bertanggungjawab untuk meningkatkan dan mengembangkan profesionalisme guru. Dalam mengembangkan profesionalisme guru, kepala sekolah dapat melakukan beberapa kegiatan, diantaranya: memberikan kesempatan kepada guru untuk mengikuti diklat atau pelatihan-pelatihan, mengikutkan guru dalam program sertifikasi, memberikan kesempatan kepada guru untuk melanjutkan studinya, melaksanakan kerjasama dengan lembaga/instansi lain, serta melaksanakan kunjungan ke sekolah lain.
\end{abstract}

Kata Kunci: kepemimpinan, kepala sekolah dan profesionalisme guru

\section{A. Pendahuluan}

Kepemimpinan merupakan salah satu bagian dari proses manajemen. Kepemimpinan memerlukan perhatian yang utama, karena melalui kepemimpinan diharapkan akan lahir tenaga-tenaga berkualitas 
Vol. V, No. 1, April 2017

dalam berbagai bidang yang pada akhirnya dapat meningkatkan sumber daya manusia yang berkualitas. Kepemimpinan adalah a property, a set characteristic-behavior pattern and personality attributes that makes certain people more effective at attaining a set goal. ${ }^{1}$

Menurut Soepardi yang dikutip oleh E. Mulyasa ${ }^{2}$, kepemimpinan adalah kemampuan untuk menggerakkan, mempengaruhi, memotivasi, mengajak, mengarahkan, menasehati, membimbing, menyuruh, memerintah, melarang, dan bahkan menghukum (kalau perlu), serta membina dengan maksud agar manusia sebagai media manajemen mau bekerja dalam rangka mencapai tujuan administrasi secara efektif dan efisien.

Pimpinan tertinggi disebuah lembaga pendidikan adalah kepala sekolah. Kedudukan kepala sekolah sangatlah penting. Sebagaimana yang diungkapkan oleh Made Pidarta, kepala sekolah merupakan kunci kesuksesan sekolah dalam mengadakan perubahan. ${ }^{3}$ Kepala sekolah juga disebut sebagai the key person (penanggungjawab utama atau faktor kunci) dalam menggerakkan potensi sekolah dan mempunyai otoritas penuh dalam mengelola sekolah termasuk melakukan pengelolaan dan pengembangan profesionalisme guru.

Guru merupakan salah satu faktor penentu tinggi rendahnya mutu pendidikan. Dengan kata lain, untuk meningkatkan mutu pendidikan dibutuhkan guru yang profesional. Sebagai pendidik profesional, guru

1 Tony Kippenberger, Leadership Styles, (United Kinfdom: Capstone Publisging, 2002), h. 7.

2 E. Mulyasa, Menjadi Kepala Sekolah Profesional, (Bandung: Remaja Rosdakarya, 2005), h. 42

${ }^{3}$ Made Pidarta, Cara Belajar Di Universiti Negara Maju: Suatu Studi Kasus, (Jakarta: Bumi Aksara, 1990), h. 75 
mempunyai tugas utama mendidik, mengajar, membimbing, mengarahkan, melatih, menilai, dan mengevaluasi peserta didik pada pendidikan anak usia dini jalur pendidikan formal, pendidikan dasar, dan pendidikan menengah. ${ }^{4}$

Profesi guru dalam mengajar membutuhkan pengembangan. Kenyataan menunjukkan bahwa kemajuan sekolah sangat ditentukan oleh pengembangan profesi guru. Menurut Soetopo ${ }^{5}$, dasar yang digunakan mengapa profesi keguruan harus dikembangkan ialah sebagai berikut:

1. Dasar filosofis. Tuntutan zaman dan tuntutan anak didik selalu berkembang dari waktu ke waktu. Untuk itu, profesi guru harus selalu dikembangkan agar tidak tertinggal dari kemajuan zaman.

2. Dasar psikologis. Guru selalu berhadapan dengan individu lain yang memiliki keunikan dan kekhasan masing-masing. Jika guru tidak selalu meningkatkan pemahaman terhadap individu lain (anak didik), ia tidak akan dapat menerapkan strategi pelayanannya sesuai dengan keunikan anak didik. Di sinilah pentingnya guru mengembangkan pemahaman aspek psikologis individu lain.

3. Dasar pedagogis. Tugas profesional utama guru adalah mendidik dan mengajar. Untuk dapat menjalankan tugas mendidik dan mengajar dengan baik, guru harus selalu membina diri untuk mengetahui dan menerapkan strategi mengajar baru, metode

\footnotetext{
${ }^{4}$ Undang-undang Republik Indonesia Nomor 14 tahun 2005 tentang guru dan dosen.

${ }^{5}$ Soetopo, Pendidikan dan Pembelajaran, (Malang: UMM Pres, 2005), h. 209-211
} 
Vol. V, No. 1, April 2017

baru, dan teknik-teknik mendidik yang baru; menciptakan suasana pembelajaran yang bervariasi; mampu mengelola kelas dengan baik. Untuk itu, guru harus mengikuti perkembangan inovasi pada bidang metode pembelajaran.

4. Dasar ilmiah. Ilmu pengetahuan, teknologi, dan seni selalu berkembang dengan pesat. Guru harus dapat mengembangkan cara berpikir ilmiah agar dapat selalu mnengikuti perkembangan IPTEK tersebut.

5. Dasar sosiologis. Guru harus pandai-pandai mengadakan hubungan sosial dengan mendayagunakan sarana dan media yang berkembang begitu pesat ini.

Beberapa hal inilah yang mengharuskan profesi guru perlu dikembangkan. Dan dalam mengembangkan profesionalisme guru, kepala sekolah sebagai ujung tombak utama dalam mengelola pendidikan, diharapkan mampu melaksananakan beberapa strategi atau beberapa kegiatan terkait usaha dalam pengembangan profesionalisme guru.

\section{B. Pembahasan}

1. Kepemimpinan Kepala Sekolah

Begitu banyak defenisi yang dikemukakan oleh para ahli dan peneliti mengenai kepemimpinan. Menurut Bass dan Stogdill kepemimpinan adalah suatu kegiatan dalam membimbing suatu 
Rika Ariani

kelompok sedemikian rupa, sehingga tercapailah tujuan dari kelompok itu. ${ }^{6}$

Kepemimpinan juga diartikan sebagai suatu proses kegiatan seseorang untuk menggerakkan orang lain, untuk melaksanakan sesuatu dengan memimpin, membimbing, mempengaruhi orang lain, untuk melakukan sesuatu agar tercapai hasil yang diharapkan. ${ }^{7}$ Menurut Hoy dan Miskel, kepemimpinan adalah pengaruh antar pribadi yang dijalankan dalam suatu situasi tertentu, yang diarahkan melalui proses komunikasi ke arah satu atau beberapa tujuan tertentu. $^{8}$

Ricky W. Griffin dan Gregory Moorhead ${ }^{9}$ membagi defenisi kepemimpinan menjadi dua bagian yaitu sebagai proses dan properti. Sebagai suatu proses, kepemimpinan adalah penggunaan pengaruh tanpa paksaan untuk mengarahkan dan mengkoordinasikan kegiatan anggota kelompok ke arah pencapaian tujuan. Sebagai properti, kepemimpinan adalah karakteristik yang dikaitkan dengan orang-orang yang dianggap mempekerjakan pengaruh tersebut berhasil. Dari sudut pandang organisasi, kepemimpinan adalah yang sangat penting karena memiliki pengaruh yang kuat seperti pada perilaku individu dan kelompok.

6 N.A. Ametembun, Kepemimpinan Pendidikan, (Malang: IKIP Malang, 2005), h. 1 - 2

${ }^{7}$ Edy Sutrisno, Manajemen Sumber Daya Manusia, (Jakarta: Kencana Prenada Mediagroup, 2012), h. 213

${ }^{8}$ Hoy k. Wayne dan Miskel. G. Cecuil, Educational Administration, (New York: The McGraw-Hill Companies, Inc.2008), h. 418

${ }^{9}$ Ricky W. Griffin dan Gregory Moorhead, Organization Behavior (Boston: Hougton Mifalin Company, t.th), h. 347 
Vol. V, No. 1, April 2017

Kepemimpinan menurut Yaverbaum dan Sherman, "leadership is act of gaining cooperation from people in order to accomplish something" (kepemimpinan adalah tindakan mendapatkan kerjasama dari orang untuk mencapai sesuatu. ${ }^{10}$ Sedangkan makna pemimpin menurut Nanang Fattah adalah seseorang yang mempunyai kemampuan untuk mempengaruhi perilaku orang lain didalam kerjanya dengan menggunakan kekuasaan. ${ }^{11}$ Dalam bukunya Veithzal Rivai, menjelaskan bahwa pemimpin adalah seseorang yang mempunyai keahlian memimpin, mempengaruhi tanpa menanyakan alasan-alasannya. Pemimpin adalah orang pilihan yang memiliki kemampuan dalam mewujudkan tujuan. ${ }^{12}$

Dari beberapa pengertian kepemimpinan di atas, dapat ditarik benang merah bahwa pada dasarnya kepemimpinan merupakan kemampuan seseorang untuk meyakinkan orang lain agar mau melakukan kehendak dan perintahnya pada keadaan tertentu untuk mencapai tujuan yang diinginkan.

Terkait dengan kepemimpinan, Allah SWT berfirman di dalam surat Al- An'am ayat 165:

${ }^{10}$ Husaini Usman, Manajemen Teori, Praktik Dan Riset Pendidikan, (Jakarta: Bumi Aksara, 2009), h. 293

${ }^{11}$ Nanang Fattah, Landasan Manajemen Pendidikan, (Bandung: PT Remaja Rosdakarya, 2013), h. 6

${ }^{12}$ Veithzal Rivai, Bachtiar dan Boy Rafli Amar, Pemimpin Dan Kepemimpinan Dalam Lembaga, (Jakarta: Raja Grapindo Persada, 2013), h. 1-3 


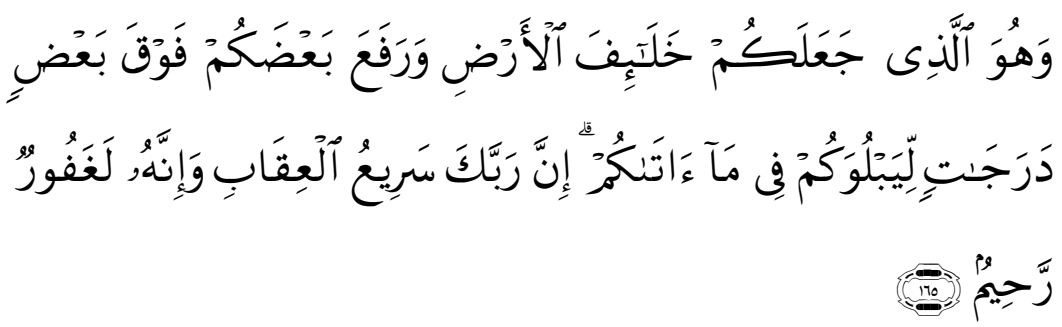

"Dan Dia-lah yang menjadikan kamu sebagai khalifahkhalifah di bumi dan Dia mengangkat (derajat) sebagian kamu di atas yang lain, untuk mengujimu atas (karunia) yang diberikan-Nya kepadamu. Sesungguhnya Tuhanmu sangat cepat memberi hukuman dan sungguh, Dia Maha Pengampun, Maha Penyayang". ${ }^{13}$

Ayat ini menjelaskan bahwa hakikat diutusnya para Rasul sebenarnya hanyalah untuk memimpin umat dan mengeluarkannya dari kegelapan kepada cahaya yang terang benderang. Makna hakiki kepemimpinan dalam Islam adalah untuk mewujudkan khilafah dimuka bumi, demi terwujudnya kebaikan dan reformasi.

Dalam sebuah organisasi pendidikan, yang menjadi pemimpin pendidikan adalah kepala sekolah. Kata kepala sekolah berasal dari dua kata yakni kepala dan sekolah. Kata kepala dapat diartikan sebagai ketua atau pemimpin dalam suatu organisasi, sedangkan sekolah adalah sebuah lembaga di mana menjadi tempat menerima dan memberi penjelasan. ${ }^{14}$ Menurut pengertiannya, kepala sekolah adalah tenaga fungsional guru yang diberikan tugas tambahan untuk memimpin suatu sekolah dimana diselenggarakan

${ }^{13}$ Departemen Agama, Al-Qur'an Terjemah dan Asbabun Nuzul, (Jakarta, CV Al Hanan, 2009), h. 150

14 Wahjosumidjo, Kepemimpinan Kepala Sekolah: Tinjauan Teoritik Dan Permasalahannya, (Jakarta: Raja Grapindo Persada, 2005), h. 82 
Vol. V, No. 1, April 2017

proses belajar mengajar atau tempat dimana terjadi interaksi antara guru yang memberi pelajaran dan murid yang menerima pelajaran. $^{15}$

Fungsi kepemimpinan dalam dunia pendidikan adalah sebagai leader dan educator dalam rangka meningkatkan mutu pendidikan. Mutu pendidikan akan tercapai apabila didukung oleh seluruh komponen pendidikan yang terorganisir dengan baik. Beberapa komponen tersebut adalah input, proses, dan output dan ini perlu mendapatkan dukungan sepenuhnya dari pihak yang mempunyai peran penting dalam lembaga pendidikan, dalam hal ini adalah kepala sekolah. Sebab kepala sekolah merupakan pemimpin pendidikan yang berhubungan langsung dalam pelaksanaan program pendidikan di sekolah. Kepala sekolah sebagai penentu kebijakan di sekolah harus memfungsikan perannya secara maksimal dan mampu memimpin sekolah dengan bijak dan terarah, serta mengarah kepada pencapaian tujuan yang maksimal pula, demi meningkatkan mutu pendidikan. ${ }^{16}$

Sebagai pemimpin pendidikan, kepala sekolah memiliki sejumlah tugas dan tanggung jawab yang cukup berat. Untuk bisa menjalankan fungsinya secara optimal, kepala sekolah perlu menerapkan gaya kepemimpinan yang tepat.

${ }^{15}$ Ibid, h. 83

16 Abdullah Munir, Menjadi Kepala Sekolah Efektif, (Jogjakarta: Ar-Ruzz Media, 2008), hal. 6 
Peran utama kepala sekolah sebagai pemimpin pendidikan adalah menciptakan situasi belajar mengajar sehingga guru-guru dapat mengajar dan siswa dapat belajar dengan baik.

Menurut Wahyusumidjo ${ }^{17}$, peranan kepala sekolah sebagai pemimpin pendidikan mencerminkan tanggung jawab kepala sekolah untuk menggerakkan seluruh sumber daya yang ada di sekolah, sehingga lahir etos kerja dan produktivitas yang tinggi dalam mencapai tujuan. fungsi kepemimpinan ini sangat penting, sebab di samping sebagai penggerak juga berperan untuk melakukan kontrol segala aktifitas guru (dalam rangka meningkatkan profesional mengajar), staff dan siswa sekaligus untuk meneliti persoalan-persoalan yang timbul di lingkungan sekolah.

\section{Pengembangan Profesionalisme Guru}

Kata "Profesional" berasal dari kata sifat yang berarti pencaharian dan sebagai kata benda yang berarti orang yang mempunyai keahlian, seperti guru, dokter, hakim dan sebagainya. Dalam pengertian lain, profesional adalah pekerjaan atau kegiatan yang dilakukan oleh seseorang dan menjadi sumber penghasilan kehidupan yang memerlukan keahlian, kemahiran, atau kecakapan yang memenuhi standar mutu atau norma tertentu serta memerlukan pendidikan profesi. ${ }^{18}$ Pekerjaan yang bersifat profesional adalah pekerjaan yang hanya dapat dilakukan oleh mereka yang khusus

${ }^{17}$ Wahyusumidjo, Op. Cit, hal. 90

18 Undang -undang Guru dan Dosen, ( Jakarta, Sinar Grafika, 2010), h. 03 
Vol. V, No. 1, April 2017

dipersiapkan untuk itu dan bukan pekerjaan yang dilakukan oleh mereka yang karena tidak dapat memperoleh pekerjaan lain. ${ }^{19}$

Sedangkan yang dimaksud dengan guru adalah pendidik profesional dengan tugas utama mendidik, mengajar, membimbing mengarahkan, melatih, menilai, dan mengevaluasi peserta didik pada pendidikan formal, pendidikan dasar, dan pendidikan menengah. ${ }^{20}$ Untuk menjadi guru diperlukan syarat-syarat khusus, apalagi sebagai guru pofesional yang harus menguasai betul seluk beluk pendidikan dan pengajaran dengan berbagai pengetahuan lainnya yang perlu dibina dan dikembangkan melalui masa pendidikan tertentu atau pendidikan prajabatan.

Dengan bertitik tolak pada pengertian ini, maka pengertian guru profesional adalah orang yang memiliki kemampuan dan keahlian khusus dalam bidang keguruan sehingga ia mampu melakukan tugas dan fungsinya sebagai guru dengan kemampuan maksimal atau dengan kata lain, guru profesional adalah orang yang terdidik dan terlatih dengan baik, serta memiliki pengalaman yang kaya dibidangnya. ${ }^{21}$

Adapun syarat yang harus dimiliki oleh seorang guru profesional diantaranya adalah: ${ }^{22}$ (a) Menuntut adanya ketrampilan yang berdasarkan konsep dan teori ilmu pengetahuan yang

19 Kunandar, Guru Profesional Implementasi Kurikulum Tingkat Satuan Pendidikan (KTSP) dan Sukses dalam Sertifikasi Guru, (Jakarta: Rajawali Press, 2009), h.45

${ }^{20}$ Undang -undang Guru dan Dosen... h. 03

${ }^{21}$ Ibid, h.46

22 Basyirudin Usman, Guru Profesional dan Implementasi Kurikulum, ( Jakarta, Ciputat Pers, 2002), h. 25 
mendalam, (b) Menekankan pada suatu keahlian dalam bidang tertentu sesuai dengan bidang profesinya, (c) Menuntut adanya tingkat pendidikan keguruan yang memadai, (d) Adanya kepekaan terhadap dampak kemasyarakatan dari pekerjaan yang dilaksanakannya, (e) Memenungkinkan perkembangan sejalan dengan dinamika kehidupan.

Dengan demikian, untuk menjadi guru profesional seseorang harus menempuh jenjang pendidikan tertentu dan harus memiliki kompetensi-kompetensi tertentu. Empat kompetensi yang harus dimiliki oleh seorang guru adalah: kompetensi pedagogik, kompetensi kepribadian, kompetensi profesional, dan kompetensi sosial.

Lebih rinci penulis uraikan keempat kompetensi guru sebagai berikut:

a. Kompetensi Pedagogik yaitu suatu kompetensi yang mampu mengelola pembelajaran. Ini mencakup konsep kesiapan mengajar yang ditunjukkan oleh penguasaan pengetahuan dan keterampilan mengajar. Mengajar merupakan pekerjaan yang kompleks dan sifatnya multidimensional. ${ }^{23}$

b. Kompetensi Kepribadian

Adalah suatu kompetensi yang memiliki kemampuan personal yang mencerminkan kepribadian yang mantap, stabil, dewasa, arif dan berwibawa, menjadi teladan peserta didik, dan berakhlak mulia. Guru sebagai teladan akan mengubah prilaku

23 Buchari Alma, Guru Professional (Menguasai Metode dan Terampil Mengajar), (Bandung, Alfabeta, 2009), hal. 141 
Vol. V, No. 1, April 2017

siswa, guru adalah panutan. Guru yang baiak akan dihormati dan disegani oleh siswa. Jadi guru harus bertekad mendidik dirinya sendiri lebih dulu sebelum mendidik orang lain. Pendidikan melalui keteladanan adalah pendidikan yang paling efektif. Guru yang disenangi, otomatis mata pelajaran yang ia ajarkan akan disenangi oleh siswa, dan siswa akan semangat dan termotivasi sendiri mendalami mata pelajaran tersebut. Sebaliknya guru yang dibenci oleh murid, akan tidak senang dengan mata pelajaran yang dipegang oleh guru, dan membentuk sikap antipati terhadap mata pelajaran yang dipelajari tesebut. ${ }^{24}$

c. Kompetensi Profesional

Adalah suatu kompetensi yang memiliki kemampuan penguasaan materi pelajaran secara luas dan mendalam, serta metode dan teknik mengajar yang sesuai yang dipahami oleh murid, mudah ditangkap, tidak menimbulkan kesulitan dan keraguan, yang mencakup penguasaan materi kurikulum mata pelajaran di sekolah dan subtansi keilmuan yang menaungi materinya, serta penguasaan terhadapstruktur dan metodologi keilmuannya.

d. Kompetensi sosial

Adalah suatu kompetensi yang memiliki kemampuan guru untuk berkomunikasi dan berinteraksi secara efektif dengan lingkungan sekolah dan di luar lingkungan sekolah. Guru

24 Buchari Alma, Guru Professional (Menguasai Metode dan Terampil Mengajar), (Bandung, Alfabeta, 2009), h. 141-142 
profesional berusaha mengembangkan komunikasi dengan orang tua siswa, sehingga terjalin komunikasi dua arah yang berkelanjutan antara sekolah dan orang tua, serta masyarakat pada umumnya. $^{25}$

Gary dan Margett mengemukakan bahwa guru yang efektif dan kompeten secara profesional memiliki karakteristik sebagai berikut:

a. Memiliki kemampuan menciptakan iklim belajar yang kondusif;

b. Memiliki kemampuan mengembangkan strategi dan manajemen pembelajaran;

c. Memiliki kemampuan memberikan umpan balik (feedback) dan penguatan (reinforcement);

d. Memiliki kemampuan untuk peningkatan diri. Kemampuan untuk peningkatan diri, antara lain menerangkan kurikulum dan metode mengajar secara inovatif, memperluas dan menambah pengetahuan tentang metode pembelajaran, dan memanfaatkan kelompok (KKG) unstuck menciptakan dan mengembangkan metode pengajaran yang relevan. ${ }^{26}$

Menurut kurikulum 1975, tanggungjawab pembinaan guru berada di tangan kepala sekolah dan penilik sekolah. Menurut Gwynn tanggungjawab pembinaan guru berada di tangan supervisor yang terdiri dari:

general

${ }^{25}$ Ibid, h. 142

26 Mulyasa, Menjadi Kepala Sekolah Profesional Dalam Konteks Menyukseskan MBS dan KBK, (Bandung: PT. Remaja Rosdakarya, 2003), h. 100 
Vol. V, No. 1, April 2017

supervisor, special grade supervisor, special subject supervisor, yang ketiga-tiganya dikoordinasi oleh super intendent. Mengingat yang hampir bertemu setiap hari dengan guru di sekolah adalah kepala sekolah, dan bukan pembina yang lainnya, maka kepala sekolahlah yang paling banyak bertanggungjawab dalam pembinaan profesionalisme guru. ${ }^{27}$

Menurut Abuddin $\mathrm{Nata}^{28}$, pembinaan tenaga guru yang profesional perlu dilakukan karena guru yang profesionallah yang akan mendukung peningkatan mutu pendidikan. Guru yang profesional dalam pandangan Islam, selain harus memiliki kompetensi pedagogik, kepribadian, sosial, dan akademik, harus didasarkan pada visi dan spirit ajaran Islam sehingga memiliki makna ibadah kepada Allah SWT dan terhindar dari pengaruh materialisme dan hedonisme yang menjadi sebab jatuhnya mutu pendidikan. Menurutnya pula, dalam rangka meningkatkan mutu guru profesional, perlu dipertimbangkan untuk menghidupkan kembali sekolah-sekolah keguruan. Sebuah kolaborasi antara fakultas keguruan dan non keguruan yang melibatkan kaum profesional sebagai tenaga pengajar pada pendidikan profesi keguruan dengan menerapkan sistem magang; konsep guru berantai dan berjenjang; tutor sebaya. Semua kegiatan tersebut dimonitor, disupervisi, dan dibina oleh guru senior berpengalaman dan profesional dalam mendidik calon-calon guru.

27 Wahjosumidjo, Kepemimpinan Kepala Sekolah Tinjauaan Teoritis dan Permasalahannya, (Jakarta: PT Raja Grafindo Persada, 3003), h.89

${ }_{28}$ Abuddin Nata, Kapita Selekta Pendidikan Islam, (Jakarta: Raja Grapindo Persada, 2012), h. 231 
Pembinaan profesionalisme guru dimaksudkan sebagai serangkaian usaha pemberian bantuan kepada guru terutama bantuan berwujud bimbingan profesional yang dilakukan oleh kepala sekolah, pengawas dan oleh pembina sesama guru lainnya untuk meningkatkan proses dan hasil belajar mengajar. Bimbingan profesional yang dimaksud adalah kegiatan yang dapat meningkatkan kemampuan profesionalisme guru terutama dalam proses belajar mengajar. Disamping itu pembinaan guru juga dimaksudkan sebagai usaha terlaksananya sistem kenaikan pangkat dalam jabatan profesional guru. ${ }^{29}$

Suprihatiningrum $^{30}$, mendefinisikan pengembangan profesi guru sebagai suatu proses untuk membantu guru dalam melakukan pekerjaan secara efektif. Dan tujuan pengembangan guru ialah mewujudkan guru profesional sesuai harapan sekolah.

Pengembangan profesi guru juga dapat didefenisikan sebagai usaha-usaha yang dilakukan oleh kepala sekolah untuk meningkatkan mutu kinerja guru. Pengembangan merupakan tindak lanjut dari peningkatan profesionalisme guru. Menurut Suharsaputra, terdapat beberapa strategi yang bisa dilakukan untuk menciptakan situasi yang kondusif bagi pengembangan profesi guru, yaitu sebagai berikut:

29 Kunandar, Guru Profesional Implementasi Kurikulum Tingkat Satuan Pendidikan (KTSP) dan Sukses dalam Sertifikasi Guru, (Jakarta: Rajawali Press, 2009), h.134

${ }^{30}$ Suprihatiningrum, Guru Profesional, (Yogyakarta: Ar-Ruzz Media, 2013), h. 172 
Vol. V, No. 1, April 2017

a. Strategi perubahan paradigma. Strategi ini dimulai dengan mengubah paradigma birokrasi agar menjadi mampu mengembangkan diri sendiri sebagai institusi yang berorientasi pelayanan, bukan dilayani.

b. Strategi debirokrartis. Strategi ini dimaksudkan unstuck mengurangi tingkatan birokrasi yang dapat menghambat pada pengembangan diri pendidik.

\section{Kegiatan Pengembangan Profesi Guru}

Pengembangan profesi guru merupakan hal yang sangat urgen. Guru merupakan salah satu komponen yang berperan dalam usaha pembentukan sumber daya yang potensial dalam pembangunan. Para guru diharapkan memiliki pengetahuan, keterampilan, serta sikap yang cermat terhadap setiap perubahan. Meningkatnya kualitas guru akan mendorong peningkatan kualitas pendidikan di Indonesia, baik proses maupun hasilnya. Sekolah akan bermutu apabila tersedia guru yang profesional.

Tugas kepala sekolah dalam kaitannya dengan pengembangan profesi guru bukanlah pekerjaan yang mudah. Oleh karenanya, kepala sekolah pun dituntut profesional dalam mengemban tugasnya, khususnya dalam mengelola dan meningkatkan profesionalisme guru. Menurut Collete dan Ciappetta yang dikutip oleh Suprihartiningrum ${ }^{31}$, kegiatan pengembangan profesi guru dapat ditempuh melalui beberapa cara, yaitu studi lanjut, inservise training, memberdayakan musyawarah 
guru mata pelajaran (MGMP), memberdayakan organisasi profesi, dan mengevaluasi kinerja mengajar di kelas, sertifikasi, dan uji kompetensi.

Menurut Rohiat ${ }^{32}$, sasaran pengembangan guru sesuai dengan SNP, antara lain: 1) Peningkatan kompetensi guru bidang pengembangan kurikulum; 2) Peningkatan kompetensi guru bidang manjemen pembelajaran; 3) Peningkatan kompetensi guru bidang pengembangan strategi pembelajaran (CTL), mastery learning, dan pakem; 4) Peningkatan kompetensi guru bidang pengembangan media pembelajaran; 5) Peningkatan kompetensi guru dalam penggunaan ICT (komputer, internet, dan perangkat ICT lainnya); 6) Peningkatan kompetensi dalam PTK; 7) Peningkatan kompetensi dalam bidang bahasa inggris.

Strategi yang dapat dilakukan untuk mewujudkan sasaransasaran tersebut, antara lain: 1) Melaksanakan workshop/pelatihan secara internal di sekolah; 2) Mengirimkan guru dalam MGMP; 3) Melaksanakan kerjasama dengan LPMP; 4) Melaksanakan in house training; 5) Melaksanakan kerjasama dengan lembaga/instansi lain, khususnya dalam peningkatan guru bidang ICT; 6) Melaksanakan magang dan kunjungan ke sekolah lain; 7) Melaksanakan kerja sama dengan LPTI dan perguruan tinggi.

Hal senada dikemukakan oleh Imam Musbikin, bahwa dalam mengembangkan profesionalisme guru ada beberapa hal yang dapat dilakukan oleh kepala sekolah sebagai berikut:

\footnotetext{
${ }^{32}$ Rohiat, Manajemen Sekolah, (Bandung: Refika Aditama, 2008), h. 86
} 
Vol. V, No. 1, April 2017

a. Mengikutsertakan guru dalam berbagai forum ilmiah (diklat/inservice training).

b. Mengikutkan dalam program sertifikasi guru, di mana tujuan sertifikasi guru adalah: a) menentukan kelayakan guru dalam melaksanakan tugas sebagai agen pembelajaran, b) meningkatkan profesionalisme guru, c) mengangkat harkat dan martabat guru.

c. Studi lanjut atau tugas belajar ke jenjang pendidikan yang lebih tinggi agar kualifikasi akademiknya meningkat dan sesuai dengan standar yang ditetapkan oleh pemerintah.

d. Revitalisasi dan optimalisasi organisasi profesi guru seperti MGMP.

e. Peningkatan pelayanan dan penambahan fasilitas penunjang, seperti fasilitas lab komputer, lab bahasa, perpustakaan, dan sambungan internet agar guru-guru dapat memanfaatkannya.

f. Meningkatkan tunjangan kesejahteraan guru.

g. Membentuk forum silaturrahmi antar guru.

h. Melakukan studi banding dan kunjungan secara personal ke sekolah lain. ${ }^{33}$

Usaha-usaha yang dilakukan dalam rangka pengembangan profesi guru tentu membutuhkan kerja keras. Apabila profesi guru tersebut selalu dikembangkan, akan menghasilkan guru-guru yang berkualiatas dan pada akhirnya akan berdampak pada keberhasilan pendidikan. Unstuck itu, usaha-usaha pengembangan tersebut perlu

33 Imam Musbikin, Menjadi Kepala Sekolah Yang Hebat, (Riau: Zanafa Publishing, 2013), h. 69-75 
dukungan penuh dari berbagai pihak, yaitu kepala sekolah, kepala dinas pendidikan, dan pemangku kepentingan lainnya.

\section{Penutup}

Kepala sekolah adalah tenaga fungsional guru yang diberikan tugas tambahan untuk memimpin suatu sekolah di mana diselenggarakan proses belajar mengajar atau tempat di mana terjadi interaksi antara guru yang memberi pelajaran dan murid yang menerima pelajaran. Salah satu peran kepala sekolah sebagai pimpinan tertinggi di sebuah lembaga pendidikan adalah mengembangkan profesionalisme guru, karena sebagaimana yang diketahui guru merupakan komponen yang paling berpengaruh dalam proses dan hasil pendidikan. Guru adalah penentu keberhasilan pendidikan.

Pengembangan profesi guru pada dasarnya adalah peningkatan kualitas dimensi-dimensi kompetensi guru. Beberapa dimensi utama dalam kompetensi guru adalah: kompetensi pedagogik, kompetensi kepribadian, kompetensi profesional, dan kompetensi sosial.

Pengembangan profesi guru merupakan strategi yang dapat membantu guru agar lebih efektif dalam melaksanakan tugasnya. Tujuan utama pengembangan profesionalisme guru adalah mewujudkan guru profesional sesuai harapan sekolah.

Dalam rangka pengembangan profesionalisme guru, ada beberapa hal yang dapat dilakukan oleh kepala sekolah, yaitu: mengikutsertakan guru dalam berbagai forum ilmiah (diklat/inservice training), mengikutkan dalam program sertifikasi guru, studi lanjut atau tugas belajar ke jenjang pendidikan yang lebih tinggi, revitalisasi dan 
Vol. V, No. 1, April 2017

optimalisasi organisasi profesi guru seperti MGMP, peningkatan pelayanan dan penambahan fasilitas penunjang, meningkatkan tunjangan kesejahteraan guru serta membentuk forum silaturrahmi antar guru. 
Rika Ariani

\section{DAFTAR PUSTAKA}

Abdullah Munir, 2008, Menjadi Kepala Sekolah Efektif, Jogjakarta: ArRuzz Media.

Abuddin Nata, 2012, Kapita Selekta Pendidikan Islam, Jakarta: Raja Grapindo Persada.

Basyirudin Usman, , 2002, Guru Profesional dan Implementasi Kurikulum, ( Jakarta, Ciputat Pers.

Buchari Alma, , 2009, Guru Professional (Menguasai Metode dan Terampil Mengajar), Bandung, Alfabeta.

Departemen Agama, , 2009, Al-Qur'an Terjemah dan Asbabun Nuzul, Jakarta, CV Al Hananx.

E. Mulyasa, , 2005, Menjadi Kepala Sekolah Profesional, Bandung: Remaja Rosdakarya.

Edy Sutrisno, 2012, Manajemen Sumber Daya Manusia, Jakarta: Kencana Prenada Mediagroup.

Gibson, James L, et. All, , 1988, Organisasi Prilaku, Struktur, Proses, Alih Bahasa: Djarkasih, Jakarta: Erlangga.

Husaini Usman, 2009, Manajemen Teori, Praktik Dan Riset Pendidikan, Jakarta: Bumi Aksara.

Imam Musbikin, 2013, Menjadi Kepala Sekolah Yang Hebat, Riau: Zanafa Publishing.

Kunandar, 2009, Guru Profesional Implementasi Kurikulum Tingkat Satuan Pendidikan (KTSP) dan Sukses dalam Sertifikasi Guru, Jakarta: Rajawali Press.

Kippenberger, Tony, 2002, Leadership Styles, United Kinfdom: Capstone Publishing. 
Vol. V, No. 1, April 2017

Made Pidarta, 1990, Cara Belajar Di Universiti Negara Maju: Suatu Studi Kasus, Jakarta: Bumi Aksara.

M. Ngalim Purwanto, dkk, 1984, Administrasi Pendidikan, (Jakarta: Mutiara Offset.

Mulyasa, 2003, Menjadi Kepala Sekolah Profesional Dalam Konteks Menyukseskan MBS dan KBK, Bandung: PT. Remaja Rosdakarya.

Nanang Fattah, 2013, Landasan Manajemen Pendidikan, Bandung: PT Remaja Rosdakarya.

N.A. Ametembun, 2005, Kepemimpinan Pendidikan, Malang: IKIP Malang.

Ricky W. Griffin dan Gregory Moorhead, Organization Behavior, Boston: Hougton Mifalin Company, t.th

Rohiat, 2008, Manajemen Sekolah, Bandung: Refika Aditama.

Soetopo, 2005, Pendidikan dan Pembelajaran, Malang: UMM Pres.

Suprihatiningrum, 2013, Guru Profesional, Yogyakarta: Ar-Ruzz Media.

Undang -undang Guru dan Dosen, Jakarta, Sinar Grafika, 2010.

Veithzal Rivai, Bachtiar dan Boy Rafli Amar, 2013, Pemimpin Dan Kepemimpinan Dalam Lembaga, Jakarta: Raja Grapindo Persada.

Wayne, Hoy k. dan Miskel. G. Cecuil, 2008, Educational Administration, New York: The McGraw-Hill Companies, Inc.

Wahjosumidjo, 2005, Kepemimpinan Kepala Sekolah: Tinjauan Teoritik Dan Permasalahannya, Jakarta: Raja Grapindo Persada. 